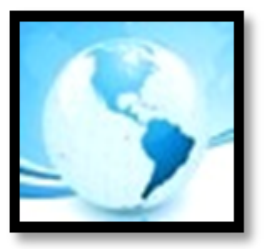

MALAYSIAN ONLINE JOURNAL OF

EDUCATIONAL MANAGEMENT

(MOJEM)

July 2019, VOLUME 7, ISSUE 3, 80 - 98

E-ISSN NO: $2289-4489$

\title{
A MODEL FOR YOUTH ENTREPRENEURSHIP SKILLS OF THE COMMUNITY-BASED LEADERSHIP TRAINING FOR THE URBAN YOUTH IN CHINA
}

Xiao Sai, Husaina Banu Kenayathulla(PhD), Siraj Saedah (PhD)

Faculty of Education,

University of Malaya, Malaysia.

Corresponding Author:

E-mail: husaina@um.edu.my 


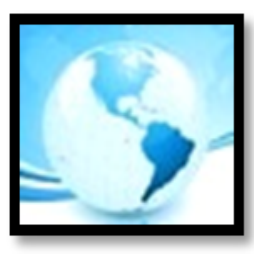

\section{INTRODUCTION}

The world population has been increasing rapidly and it has reached almost 7.6 billion in mid- 2017 (World Population Prospects, 2017). In 2015, there has been 1.2 billion youth from the ages of 15 to 24 years old in the world, accounting for one out of every six people globally (United Nation, 2015). The youth population is an important asset that determines the suitable development in every nation. In most countries, governments have invested in education sector to enhance the knowledge, skills, growth, and achievements of youth. Youth leadership development is often regarded as an investment in the future of the nation state (Gordon \& Taft, 2010). Recently, many youth leadership curricula or programs have been developed in many countries. For instance, in Malaysia, the Youth Leadership Academy (YLA) has designed a 12-week project-based leadership development program for local university students. In this YLA program, the main contents included 2 full day workshops, a project, and a unique mentoring program.

Studies have found that the Community-Based Youth Curriculum like Youth Engagement Continuum- Funders' Collaborative on Youth Organising 2003 (Brady et al., 2012) and the Step Up to leadership Curriculum (National 4-H Cooperative Curriculum System) learning have positive outcomes. These programs foster students' skill levels in leadership, relationship building, social problem solving, occupational and life skills while prompting social and civic responsibility.

In regards to China, these recent years has shown that the population of urban youth there has increased rapidly and impacted the nation greatly. The population of youth from the age of 14 to 35 years old in China is $454,010,000$ and the population of urban youth is nearly $57.74 \%$ in the end of 2012 (Including army servicemen but excluding the population of Hong Kong, the Macao Special Administrative Region and Taiwan Province) (Deng, 2015). The urban youth of China have their unique characteristics comprising the material situations of their lives, their values orientation, self-understanding and their struggles and frustrations. The great number of urban youths also impacts the development of urban cities.

The studies of youth leadership development have already been conducted and the researchers have attained significant results. Community- based leadership training curriculum or programs for the youth have been implemented in secondary schools and high schools. For example, some curricula of Leadership Development have been applied based on the program: Leadership for High School Students Program. This program is organised by the Chinese Society of Education, the Training Centre for the Secondary School and High School principals organised by Ministry of Education of China and The Commercial Press. This whole set of educational programs focused not only the youth leadership training curriculum for teaching, but also encouraged the youth leadership competitions between the schools in different provinces of China. The curriculum textbook named Leadership Development released several main types of issues namely, Improved Public Policy, International Day of Remembrance, Helping the Disadvantage Groups, Protection of Cultural Heritage, Community and school service, Establishment of Public Welfare Organisations, and Career Planning, and Organised Leadership Camp. Based on these issues, every high school can make their own different activities for training leadership for the youth.

Many high performing secondary and high schools have applied this curriculum and gained positive outcomes. Lin (2016) mentioned that, by comparing the students from a high school who learnt the curriculum of Leadership Development and those who did not, the students who learnt this curriculum showed better performances in leadership and improved in every dimension of leadership. Meanwhile, nowadays, in China, more youth leadership training curricula practiced in western countries have been explored and applied like Dale Carnegie EQ and Leadership Training for the youth, Sailing Leadership International Curriculum, Youth Leadership Curriculum Model. 


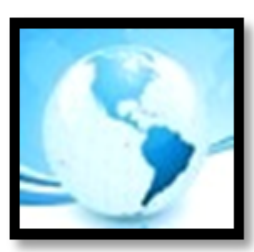

\section{MALAYSIAN ONLINE JOURNAL OF EDUCATIONAL MANAGEMENT (MOJEM)}

Although achieving the positive outcomes, the training for urban youth still needs to be paid more attention. The children/youth negligence is the problem which is more important to pay attention. Based on the research of the children/ youth negligence situation from 3 to 17 years old in urban China (Pan et al., 2012), the negligence level of high school group (from 15 to 17 years old) is the highest, especially in the areas of safety neglect and social neglect. There is an increasing social competition, especially during schooling; thus, parents tend to expect too much of their children and children are stressed. Parents are busy with work and just only focused on economic input of their children and ignore their physical development, emotion, psychological needs and changes. The youth from 15 to 17 years old who are in the period of puberty are affected by the requirements of physiology and psychology increasing greatly. They undertake more stress of entering a higher school, as the parents and schools' management prioritise the students' study results and enrolment status that make the secondary school and the high school students being neglected easily, particularly, the high school students. Hence, parents, teachers and social related departments need to adopt the corresponding effective intervening measures in advance to promoting healthy development of secondary school and high school students both physically and mentally (Pan et al., 2012). In addition, the urban youths in China need to improve youth leadership. With the accelerating world economic integration and internationalization, cultivating innovative talents have become important for each country to enhance its international competitiveness. Developing students' leadership is an important task; creative talent, leadership should be trained and developed at the secondary school and high school stage (Li \& Lang, 2012). Adolescence is an important time for leadership growth. Increasing leadership for adolescents has positive impact on self- esteem and is the catalyst for flourishing adulthood (Karagianni \& Montgomery, 2016). Last but not least, one important point is that in China, the Community - Based Leadership Training Curricula or Programs for the urban youth in China which comprise of international perspectives and local contexts are still lacking. Hence, these types of community-based leadership training curricula or programs for the urban youth in china need to be designed and developed. The main objective of the study is to design a curriculum content model for the Youth Community based Leadership Training. Based on the aforementioned objective, the specific objectives are to identify the entrepreneurship skills among the urban youth in China and to get consensus from panel of experts on the activities of entrepreneurship skills that suitable to the youth community based leadership training.

\section{THEORETICAL FOUNDATION}

Two main theories and models have been utilized to support this current study. The selected theories and models were Tyler's Model (1949) for curriculum theory and A Model for Community Based Youth Leadership Development of Susan Doherty (2003). In addition, Institute of International Education (IIE) approach to Managing Youth Leadership Programs (2014) also has been applied as the theoretical foundation. Tyler's Model (1949) has been developed by Ralph Tyler in 1949 which is a quintessential prototype of curriculum development in the scientific approach. Tyler has stated the rationale of his curriculum theory was based on four questions. Developing of any curriculum needs to answer these questions: 1) What educational purposes should the school seek to attain? 2) What educational experiences can be provided that will likely attain these purposes? 3) How can these educational experiences be effectively organized? and 4) How can we determine whether the purposes are being attained? (Lunenburg, 2011). The four-step process can be reformed based on these four questions including stating the objectives, selecting the learning experiences, organizing the learning experiences and evaluating the curriculum. Tyler's model has four major stages driving the four questions. The four major stages are goals and objectives, content, learning experiences, and evaluation. In other words, these stages are also known as Tyler's four basic principles: define the purpose of the curriculum; define the education experiences related to the purposes; define the organization of these experiences; and define the evaluation of the purposes (O'Neill, 2010). Determining the objectives of the school or class is the core. Each subject has natural objectives that indicate the mastery and all objectives need to be consistent with the philosophy of the school or class.

The Model for Community-Based Youth Leadership Development of Susan Doherty (2003) is an effective community project. In this curriculum model, the purpose of goals is to develop the knowledge, skills and 


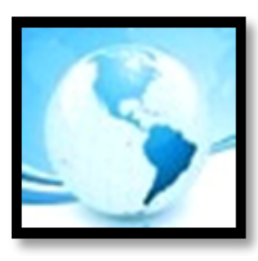

\section{MALAYSIAN ONLINE JOURNAL OF EDUCATIONAL MANAGEMENT (MOJEM)}

understanding the youths who need to be effective leaders within culturally diverse communities. This model is based on valuing and prompting growth and learning, collaboration, inclusivity, diversity, openness, creativity, flexibility, innovation and harmony. The systemic approach is also applied to identify leadership as a complicated system involving the skills, abilities, and knowledge of the "leaders", the skills, abilities, and knowledge of "followers" and the context in which all interact. The model has been designed for youth aged 14 to 19 years. The participants should be selected through application and interview process with the abilities of comprehending the complexity of skills, knowledge, and the perception needed for effective leadership. The candidates should master the basic knowledge of the community where they live and the related issues facing that community and they should possess the required intellectual abilities, creativity and human relation skills related in planning and conducting community service projects.

Community involvement is a necessary context in the community leadership development curriculum or program. This youth leadership program should be led by a committee including human service agencies, education, religious institutions, business, ethnic/cultural groups in the community and other groups interested in youth development. The community members taking part in the whole process of program planning, implementation, and evaluation should ensure that (a) the curriculum or program must be related to the community's needs and requirements; (b) the program should involve the culturally diverse values and perspectives of the community; (c) the program should be supported by a large segment of the community; (d) community members should understand more about youth issues and youth supports in the community and; (e) community members should improve their leadership development by their participation.

The focus on cultural values approaches to leadership and expected behaviours should be permeated throughout the program. This context consists of recognition of different ways of defining leadership, communicating, valuing doing and being, being comfortable with sharing perceptions and feelings with others, placing importance on humility, handling conflicts, and solving the problems. Leadership skills and knowledge issues are the important contexts of this program and these are also the requirements for the youth to develop abilities in the two areas.

In Institute of International Education (IIE) approach to Managing Youth Leadership Programs (2014), entrepreneurship skills are concluded as the main key theme. The programs offer the knowledge of entrepreneurship and the skills for enterprise start-up to motivate them to discover their creative and entrepreneurial thoughts. These activities contain the conceptual and skill-building workshops, guest lectures by entrepreneurs, field visits and business simulations.

\section{Youth Leadership Skills}

Researchers considered that leaders are both born and made. Effective leaders are born with some leadership talent and they improve their leadership qualities through training. Some hold the view that leaders are not born but everyone has the potential to become a leader by hard efforts. Leadership efficacy comes from managerial competence and support. The main three management skills include technical, interpersonal, and decision-making skills. According to MTD Training (2010), leadership skills are the tools, behaviours and abilities an individual requires to successfully motivate and direct others. Most successful leaders have a common ability: they can lead and drive others to success. An effective leader should have these skills: be committed to a vision or mission; understanding their own roles; demonstrating integrity; setting an example; having a clear awareness how to motivate others' behaviour; communicate effectively; holding the awareness of taking risks; and adept at problemsolving.

To examine youth leadership, especially on the contents of youth development, citizenship, youth action, engagement and participation are added as a complex layer (Kahn, Hewes, \& Ali, 2009). Alexander (2006) has said that, "leaders are being called upon by necessity to develop responses to complex challenges, brought on by 


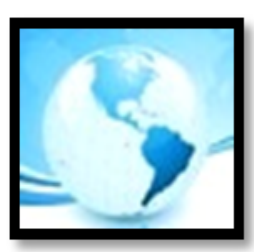

\section{MALAYSIAN ONLINE JOURNAL OF EDUCATIONAL MANAGEMENT (MOJEM)}

unexpected events and situations. Leaders of the future will have to embrace complexity and the skills needed to harness it" (Hesselbein \& Goldsmith, 2006).

When classifying the social-emotional competencies to the four clusters and making up the acronym, namely 'SEED', this is created by the Young Foundation. The ' $S$ ' refers to social and emotional competencies. These competencies comprise of self-awareness, social awareness and social skills. The first ' $E$ ' means emotional resilience. It refers to the skill of dealing with shocks or rebuffs that may occur in short or long-term. The second ' $E$ ' refers to enterprise, innovation and creativity. It shows the skill to shape situations, imagine substitutions, remain open to new ideas, problem-solving and work in teams. The ' $D$ ' is for discipline. It refers to both, the inner discipline to defer gratification and pursue goals, as well as the ability to handle the external discipline (Kahn et al., 2009). Young people learn and develop these skills in the family, their schooling and their leisure time. The leadership they learn and practice could develop the social and emotional skills, which enhance their selfconfidence and motivate them for their future (Kahn et al., 2009).

\section{The Entrepreneurship Development and Entrepreneurial Skills for Youth}

Entrepreneurship is both a practice and a process that result in creativity, innovation and enterprise development and growth. It means that, the capabilities of a person to involve and participate in socially-useful wealth creation using the innovative thinking and implication to meet the demands from consumers and requirements with one's own labour, time and ideas. Entrepreneurship changes people from "job-seekers" to "job-creators" (DSW Entrepreneurship Development Training Manual, 2009). Entrepreneurship has been developed rapidly in organisations, individuals and academicians and it is already becoming a major interest in the development of youth with regard to self-reliance (Abidin \& Bakar, 2005).

Entrepreneurship skills are a term associated with (successful) entrepreneurship. Examples of these skills include sales and marketing, self-motivation, financial and time management, administrative, management and technological skill. Hayton (2015) and Hunter (2012) have indicated that identifying customer needs, technical opportunities and market opportunities are the significant skills. Another point is to focus new opportunities creation has been put forward by Alvarez and Barney (2007) and Department for Business Innovation and Skills (2015). Entrepreneurship is meaningful in facing social challenges related to high youth unemployment. The young people are encouraged to develop initiative, confidence, calculated risk-taking, creativity, organization, and tenacity (Vassiliou, 2013).

\section{Community- Based Youth Leadership Training Curriculum}

Every excellent community-based youth leadership training curriculum or program must have a foundation of clear and definite values and have philosophical meanings that can reflect these values at the same time.

The community-based component is the necessary component of the training curricula or programs. These programs should follow the organisations such as human service agencies, education, business, religious setups, and ethnic or culture groups, which pay more attention to the youth leadership training and development.

The community members who plan, design, apply and evaluate the community based curriculum need to ensure the leadership training curriculum meet certain requirements namely the community-based curriculum or programs should be related to the community demands; the programs should involve the community's various culture conceptions and the community values; the majority of the community must approve the community based curriculum or program; the community members should have interest in youth leadership development, be clearly conscious of the youth items and give their support to the youth in the community; the community members should increase their own leadership knowledge and skills by attending the community-based training 


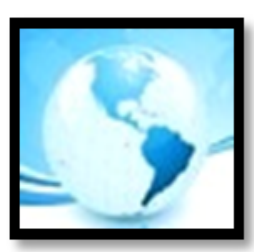

\section{MALAYSIAN ONLINE JOURNAL OF EDUCATIONAL MANAGEMENT (MOJEM)}

youth leadership curricula or programs. Such community-based programs should benefit both the youth participants and the organisers and workers involved in the community-based training (Doherty, 2003).

The community-based youth leadership training curriculum or programs should be designed to inspire the youth to explore the demands of the supports in progress and the chances of challenging to enhance the advantages of the youths.

These programs have a close relationship with the issue of positive youth development. Positive youth development means that the youth must experience the growth procedure with meeting their fundamental needs of living; moreover, the youth need more chances to socialise with peers and adults; improve their skills related to the present and the future; make the youth contribute to their communities; give them a sense of belonging to the valuable groups; and give the continuation of the youths' competing realization. These demands all are seen as the assets inspiring the effort to achieve the goals of youth development. In addition, these are the key factors of youth leadership development. The report of the Carnegie Corporation of New York has indicated that the excellent youth service organizations provide the youth leadership development curriculum or program models with positive support to enhance the principles and practices of the positive youth development (The America's Promise Alliance, 2006; Kress, 2004; Lerner, 2004; Search Institute, 1997).

\section{METHOD}

This study employed survey and Fuzzy Delphi Method (FDM) for data collection. For identifying the level of students' entrepreneurship skills, the survey method was selected as the main instrument to answer to the research questions. This study utilized FDM to design the entrepreneurship community-based leadership training curriculum content model for the urban youth in China. The target groups for this phase were young students. The survey questionnaires were distributed to 526 students aged 14 to 18 years old from the public regular high schools and secondary schools in Hebei province. This study only approached the general high schools for data collection. The students from the general high schools were representative of urban youth covering different academic record and background. Pilot study was applied before the survey questionnaires were distributed to 526 students. Fuzzy Delphi Method is adopted for the curriculum content design using experts' view. A panel of experts was chosen through purposive sampling and a total of eighteen experts from various fields in China and Malaysia to obtain the evaluation of the youth entrepreneurship skills activities which are suitable for the community-based leadership training curriculum content model.

The Delphi Method is a structured communication technique or method, originally developed as a systematic, interactive forecasting method which relies on a panel of experts. The procedure of FDM in this study as follows:

1. The experts were selected and invited to attend the questionnaire survey.

2. To address the issue of fuzziness among the experts' views and suggestions, the scale was determined to frame the respondents' feedback.

3. The experts replied with the correspondent fuzzy number scales for each questionnaire item on their view of the model. The responses were recorded in an Excel spreadsheet.

4. The difference between the experts' evaluation data and the average value for each item to identify the threshold value as " $d$ " were calculated. The calculation was performed using the formula:

Referring to the formula, $m_{1}, m_{2}$, andm $m_{3}$ stand for the average values for all the experts' views while " $n_{1}$ ", " $n_{2}$ " and " $\mathrm{n}_{3}$ " are fuzzy values for all three values for each user. 


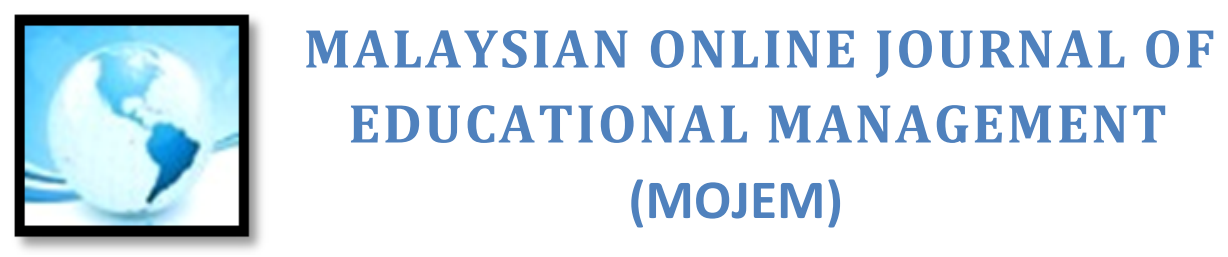

$$
d(\tilde{m}, \tilde{n})=\sqrt{\frac{1}{3}\left[\left(m_{1}-n_{1}\right)^{2}+\left(m_{2}-n_{2}\right)^{2}+\left(m_{3}-n_{3}\right)^{2}\right]} .
$$

1. From the group consensus obtained, the aggregate fuzzy elevation was determined by adding all the fuzzy numbers for each item.

2. The final step of defuzzification was conducted. The calculation was carried out using the formula:

$$
A_{\max }=1 / 4 *\left(a_{1}+2 a_{m}+a_{2}\right)
$$

In the general application of Fuzzy Delphi, defuzzification is essential to classify the variables agreed by consensus of the experts through ranking of the variables. The variable which has the highest defuzzification value was ranked highest and was prioritised to be considered as output variable. The calculation of defuzzification value and the rankings were used to identify which questionnaire items were agreed upon in this content model.

In this study, experts' evaluation was collected by the survey questionnaire. The questions consisted these items with seven point Likert scale ranging from "Not at all Important", "Low Important", "Slightly Important", "Neutral", "Moderately Important", "Very Important", "Extremely Important" which required the experts to point out their agreements. A 7-point scale is selected to fit for this questionnaire's structure. A 7-point items show that it is the best solution for questionnaires such as those used in usability evaluations (Finstad, 2010). The main element of Entrepreneurship Skills was analysed by the Fuzzy Delphi Method. In this analysis, the report was divided into 2 parts: 1). Triangular Fuzzy Numbers; 2) Defuzzification Value.

\section{1) Triangular Fuzzy Numbers :}

a) Threshold Value (d) $\leq 0.2$

For the condition 1, threshold value must equal or less than 0.2 . In the context of this study, three decimal places are used. So, every item that contains the threshold value (d) that does not reach the value of 0.3 and above will be interpreted as an agreement accepted by experts.

b) Percentage of Expert Consensus $\geq 75 \%$

Condition 2 involves the percentage of expert group agreement. This condition is based on the traditional Delphi method approach where this percentage value is determined based on the number of items containing the threshold value (d) which does not reach value 0.3 and above. This means that every item has a threshold value (d) equal to or less than 0.2 will be accept and converted to a percentage based on the traditional Delphi Method.

\section{2) Defuzzification Value:}

a) Fuzzy Score $(A) \geq \alpha-$ cut value $=0.5$

On condition 3 , the determination of the value of the fuzzy score $(A)$ is based on the value of $\alpha$-cut of 0.5 . If the score fuzzy $(A)$ is less than 0.5 , then the item being measured is rejected by consensus of the expert group. If the value is equal to 0.5 and above, then it is accepted by consensus of the expert group. Furthermore, the process of determining position and priority of items can be performed where the highest fuzzy (A) scores value is considered to be in the first position. 


\section{Pilot Study}

In the pilot study, 61 students from general high schools aged 14 years to 17 years were recruited in urban area of Baoding city in Hebei province. The education level of Baoding city is the medium in Heibei Province. Hence, the selected students are representatives to cover the different levels of academic and practical performances. The students were given 30 minutes to complete the questionnaire. The data gathered from pilot study were analysed using SPSS version 23. Questionnaire reliability was evaluated by internal consistency coefficient "Cronbach's alpha" method (Christmann \& Van Aelst, 2006). This method is based on calculation of the correlation coefficient between the different items on the same questionnaire. According to Tavakol and Dennick (2011), different reports give different acceptable values of alpha, ranging from .70 to .95. The Cronbach's alpha value for this pilot study was .965 , which was considered reliable.

Table 1

Reliability of the Instrument (Cronbach's alpha)

Cronbach's alpha N of all the Items N of Participants

.965

114

61

\section{Sample For Survey Questionnaire}

In this research, 526 youth students aged from 14 to 18 years in secondary schools and high schools in Baoding city, Shijiazhuang city, Chengde city and Handan city in Hebei Province were selected. Hebei Province is located in northern China and Beijing and Tianjin municipalities are enclave within it. There are 11 Prefectural-level cities and the provincial capital is Shijiazhuang city. With the rapid social and economic development, the needs and requirements of urban youth to develop the Community- Based Leadership Training Curriculum for the Urban Youth in China especially normal urban cities in Hebei Province becomes more significant. The selected four cities in Hebei province in this study are Shijiazhuang city, Baoding City, Handan city and Chengde city which cover the social and economic levels of Hebei Province. The students of high schools gathered from the four cities in Hebei Province are the representatives to reflect the requirements and needs of designing and developing the community-based leadership training curriculum content model for the urban youth in China.

\section{Instrumentation}

In this study, the instrument used is a set of survey questionnaire for students. The questionnaire consisted of questions divided into two parts: 1) Students' Personal Demographic; 2) Elements of Community Based Youth Leadership Training Curriculum: Entrepreneurship Skills for Youth.

The questionnaire for students was derived from Youth Skills \& Beliefs Survey from Youth Development of Executive of King County (2013); Leadership Skills Post-then-Pre-Survey: Engaging Youth, Serving Community (2010); Civic Responsibility Survey (1998); and Urban Youth Programs in America (2006). For the part of Entrepreneurship Skills for Youth, some related questions were selected from Education into Employment (EIE): Youth Entrepreneurship Training Program (2012). 


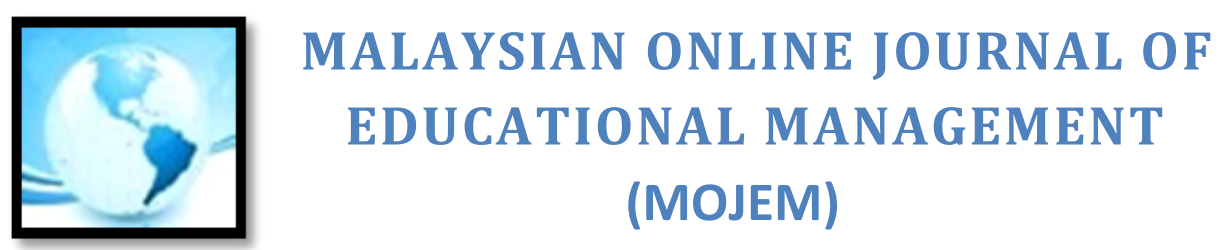

Demographic Information of Respondents

This survey questionnaire was distributed to 526 students from the secondary and high schools in Baoding city, Handan city, Shijiazhuang city and Chengde city of Hebei province in China. And the response rate was $100 \%$. Details of demographic information are presented in the Table 2.

Table 2

Demographic Information

\begin{tabular}{lcc}
\hline Gender of Students & Frequency & Percent \\
\hline Male & 254 & 48.3 \\
Female & 272 & 51.7 \\
Total & 526 & 100.0 \\
\hline Race of Students & & 86.9 \\
Han Race & 457 & 13.1 \\
Other Race & 69 & 100.0 \\
Total & 526 & 22.1 \\
\hline Cities of Students & & 21.7 \\
Baoding & 116 & 29.1 \\
Handan & 114 & 27.2 \\
Shijiazhuang & 153 & 100.0 \\
Chengde & 143 & 55.9 \\
Total & 526 & 44.1 \\
\hline Location of Students & & 100.0 \\
Urban & 294 & 2 \\
Rural & 232 & \\
Total & 526 & \\
\hline
\end{tabular}

Table 2 shows students' gender. Among 526 samples, the majority was female (51.7 \% female and $48.3 \%$ male). Furthermore, the majority of the respondents were Han Race (86.9\%) and others comprised of other races (13.1\%). The next information shows the students' cities. The students came from four cities in Hebei Province of China. The students from Baoding city were $116(22.1 \%)$; the students from Handan city were $114(21.7 \%) ;$ the students from Shijiazhuang city were 153 (29.1\%); and the students from Chengde city were 143 (27.2\%). Moreover, the information above shows that the students from Urban were 294 (55.9\%) and the students from Rural were 232 (44.1\%). Majority of the respondents were from Urban.

\section{FINDINGS}

Result of this study presented in two categories; a) Youth Entrepreneurship Skills; b) Content of Activities for Youth Entrepreneurship Skills.

\section{Youth Entrepreneurship Skills}

This section provides the answer for Research Question 1 which depicts in Table 3 the Entrepreneurship skills acquire by the students. 
Table 3

Youth Entrepreneurship Skills

\begin{tabular}{|c|c|c|c|c|c|c|c|c|c|}
\hline & \multirow[t]{2}{*}{ Item } & \multicolumn{5}{|c|}{ Competency } & \multirow[t]{2}{*}{ Mean } & \multirow[t]{2}{*}{ Std } & \multirow[t]{2}{*}{ Level } \\
\hline & & 1 & 2 & 3 & 4 & 5 & & & \\
\hline 1 & $\begin{array}{l}\text { I can identify community/ society business } \\
\text { activities and understand how these business } \\
\text { activities } \\
\text { affect individual and the community/society. }\end{array}$ & $\begin{array}{l}5.9 \\
(31)\end{array}$ & $\begin{array}{l}13.5 \\
(71)\end{array}$ & $\begin{array}{l}37.8 \\
(199)\end{array}$ & $\begin{array}{l}21.1 \\
(111)\end{array}$ & $\begin{array}{l}20.2 \\
(126)\end{array}$ & 3.37 & 1.130 & $\mathrm{H}$ \\
\hline 2 & $\begin{array}{l}\text { I am able to set goals for the future-both in } \\
\text { life and in business. }\end{array}$ & $\begin{array}{c}2.7 \\
(14)\end{array}$ & $\begin{array}{l}18.6 \\
(98)\end{array}$ & $\begin{array}{l}31.4 \\
(165)\end{array}$ & $\begin{array}{l}23.4 \\
(123)\end{array}$ & $\begin{array}{l}22.6 \\
(119)\end{array}$ & 3.45 & 1.117 & $\mathrm{H}$ \\
\hline 3 & $\begin{array}{l}\text { I can understand what is entrepreneurship } \\
\text { and the essential } \\
\text { condition of entrepreneurship. }\end{array}$ & $\begin{array}{c}6.7 \\
(35)\end{array}$ & $\begin{array}{l}20.0 \\
(105)\end{array}$ & $\begin{array}{l}31.9 \\
(168)\end{array}$ & $\begin{array}{l}21.1 \\
(111)\end{array}$ & $\begin{array}{l}18.3 \\
(96)\end{array}$ & 3.25 & 1.174 & M \\
\hline 4 & $\begin{array}{l}\text { I think I have the potential to be an } \\
\text { entrepreneur. }\end{array}$ & $\begin{array}{c}5.7 \\
(30)\end{array}$ & $\begin{array}{l}20.9 \\
(110)\end{array}$ & $\begin{array}{l}31.2 \\
(164)\end{array}$ & $\begin{array}{l}21.1 \\
(111)\end{array}$ & $\begin{array}{l}17.3 \\
(91)\end{array}$ & 3.24 & 1.156 & M \\
\hline 5 & $\begin{array}{l}\text { I can realize that creativity is important in } \\
\text { entrepreneurship. }\end{array}$ & $\begin{array}{l}2.7 \\
(14)\end{array}$ & $\begin{array}{l}9.7 \\
(51)\end{array}$ & $\begin{array}{l}22.6 \\
(119)\end{array}$ & $\begin{array}{l}26.0 \\
(137)\end{array}$ & $\begin{array}{l}36.9 \\
(194)\end{array}$ & 3.87 & 1.110 & $\mathrm{H}$ \\
\hline 6 & $\begin{array}{l}\text { I am able to understand key people and } \\
\text { organizations } \\
\text { that can assist in creating, running and } \\
\text { growing enterprises. }\end{array}$ & $\begin{array}{l}3.8 \\
(20)\end{array}$ & $\begin{array}{r}13.1 \\
(69)\end{array}$ & $\begin{array}{l}30.4 \\
(160)\end{array}$ & $\begin{array}{l}24.1 \\
(127)\end{array}$ & $\begin{array}{l}26.0 \\
(137)\end{array}$ & 3.57 & 1.133 & $\mathrm{H}$ \\
\hline 7 & $\begin{array}{l}\text { I can understand the relationship between a } \\
\text { business } \\
\text { and its external environment. }\end{array}$ & $\begin{array}{c}7.0 \\
(37)\end{array}$ & $\begin{array}{l}21.7 \\
(114)\end{array}$ & $\begin{array}{l}32.3 \\
(170)\end{array}$ & $\begin{array}{l}20.9 \\
(110)\end{array}$ & $\begin{array}{l}16.0 \\
(84)\end{array}$ & 3.17 & 1.161 & M \\
\hline 8 & I have basic economic knowledge. & $\begin{array}{c}4.4 \\
(23)\end{array}$ & $\begin{array}{l}18.3 \\
(96)\end{array}$ & $\begin{array}{l}30.4 \\
(160)\end{array}$ & $\begin{array}{l}25.1 \\
(132)\end{array}$ & $\begin{array}{l}19.0 \\
(100)\end{array}$ & 3.37 & 1.128 & $\mathrm{H}$ \\
\hline 9 & $\begin{array}{l}\text { I am able to understand the characteristics } \\
\text { and } \\
\text { traits of an entrepreneur. }\end{array}$ & $\begin{array}{l}4.2 \\
(22)\end{array}$ & $\begin{array}{l}14.8 \\
(78)\end{array}$ & $\begin{array}{l}32.9 \\
(173)\end{array}$ & $\begin{array}{l}22.4 \\
(118)\end{array}$ & $\begin{array}{l}24.0 \\
(126)\end{array}$ & 3.48 & 1.139 & $\mathrm{H}$ \\
\hline 10 & $\begin{array}{l}\text { I am able to understand and analyse business } \\
\text { location possibilities. }\end{array}$ & $\begin{array}{c}7.2 \\
(38)\end{array}$ & $\begin{array}{r}18.1 \\
(95)\end{array}$ & $\begin{array}{l}29.1 \\
(153)\end{array}$ & $\begin{array}{l}20.7 \\
(109)\end{array}$ & $\begin{array}{l}21.1 \\
(111)\end{array}$ & 3.32 & 1.218 & M \\
\hline 11 & $\begin{array}{l}\text { I am able to generate business ideas based } \\
\text { on the } \\
\text { customer's interests, my skills, gaps in the } \\
\text { market, } \\
\text { identified needs, etc. }\end{array}$ & $\begin{array}{c}6.5 \\
(34)\end{array}$ & $\begin{array}{r}18.4 \\
(97)\end{array}$ & $\begin{array}{l}31.0 \\
(163)\end{array}$ & $\begin{array}{l}24.3 \\
(128)\end{array}$ & $\begin{array}{l}18.3 \\
(96)\end{array}$ & 3.30 & 1.162 & $M$ \\
\hline 12 & $\begin{array}{l}\text { I am able to observe and begin to and } \\
\text { analyse } \\
\text { small business in community/ society. }\end{array}$ & $\begin{array}{l}8.7 \\
(46)\end{array}$ & $\begin{array}{l}20.7 \\
(109)\end{array}$ & $\begin{array}{l}33.7 \\
(177)\end{array}$ & $\begin{array}{l}21.5 \\
(113)\end{array}$ & $\begin{array}{l}14.1 \\
(74)\end{array}$ & 3.12 & 1.158 & $\mathrm{M}$ \\
\hline 13 & $\begin{array}{l}\text { I am able to develop a simple annual sales } \\
\text { plan. }\end{array}$ & $\begin{array}{l}13.3 \\
(70)\end{array}$ & $\begin{array}{l}23.4 \\
(123)\end{array}$ & $\begin{array}{l}29.5 \\
(155)\end{array}$ & $\begin{array}{l}17.5 \\
(92)\end{array}$ & $\begin{array}{l}14.4 \\
(76)\end{array}$ & 2.96 & 1.245 & M \\
\hline 14 & $\begin{array}{l}\text { I am able to evaluate a simple annual sales } \\
\text { plan. }\end{array}$ & $\begin{array}{l}14.4 \\
(76)\end{array}$ & $\begin{array}{l}22.8 \\
(120)\end{array}$ & $\begin{array}{l}29.5 \\
(155)\end{array}$ & $\begin{array}{l}16.0 \\
(84)\end{array}$ & $\begin{array}{l}15.8 \\
(83)\end{array}$ & 2.96 & 1.274 & $\mathrm{M}$ \\
\hline
\end{tabular}

Table 3 shows the level of entrepreneurship skills of the students. Most of the items shows medium level of competency. Among the 14 items, 8 items show medium level of competency, and 6 items show high level of competency. For example, on the ability of realizing that creativity is important in entrepreneurship, the students possessed the highest competency level $(M=3.87, S D=1.110)$. In addition, the second highest level of competency is to understand key people and organizations that can assist in creating, running and growing enterprises $(M=3.57, S D=1.133)$. Students also reported medium level of competency. Among the items with medium level of competency, the students hold the highest competency level to understand and analyse business 


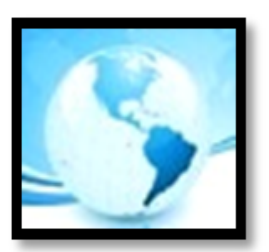

\section{MALAYSIAN ONLINE JOURNAL OF EDUCATIONAL MANAGEMENT (MOJEM)}

location possibilities $(M=3.32, S D=1.218)$. The lowest competency level is possessed by students to develop a simple annual sales plan $(M=2.96, S D=1.245)$ and to evaluate a simple annual sales plan $(M=2.96, S D=1.274)$.

\section{Activities of Entrepreneurship Skills of Youth Community-based Leadership Training Curriculum Content}

The purpose of this section is to answer Research Question 2: What are the activities in Community-Based Leadership Training Curriculum Content Model for the Urban Youth in China?

The findings from the survey show that the entrepreneurship skills are still low for certain items. Hence, the Fuzzy Delphi Method was used to get expert consensus on the type of activities that can be conducted for urban youth to develop their entrepreneurship skills.

The following are 3 steps taken to process fuzzy Delphi data:

a. Mapping of the Community-Based Leadership Training Curriculum Content Literature Model for the urban youth in China (For the Entrepreneurship Skills)

b. Interview for the Experts (Entrepreneurship Skills)

c. Process of Fuzzy Delphi Method

\section{Result Of Fuzzy Delphi Method}

Mapping of the basic Entrepreneurship Skills Community-Based Leadership Training Curriculum Content for the urban youth in China can be seen in Table 4.

Table 4

Mapping of the Basic Skills for Youth Entrepreneurship

The Basic Entomic Knowledge;

Creativity is important in entrepreneurship; Generating business ideas based on the customer's interests, my skills, gaps in the market, identified needs, etc;

Understanding the characteristics and traits of an entrepreneur (Youth Entrepreneurship Training Program Second Phase, 2013).
1. The activities of financial literacy and personal finance (The ASPIRA Youth Leadership Development Curriculum: Facilitator's Guide, 2012)

2. The activities of learning on how start up online business legally.

3. The lecture activities of successful entrepreneur to sharing their experiences to make the youth start to learn entrepreneurship.

4. Visiting the Local Famous Enterprises.

5. Joining adults in the Business Activities such as the youth sell products in supermarket when they are in school holiday.

Based on mapping of the literature, Table 4 shows that there are four types of knowledge and five types of activities that are needed to develop entrepreneurship skills of urban youth in China. The interview of Experts being conducted to seven experts, not the response alternatives. It is good for researchers to collect and gather more useful information as the extra details given by the interviewee. 


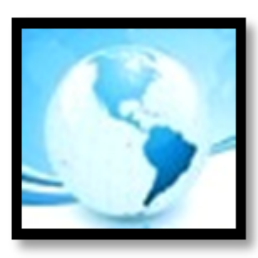

\section{MALAYSIAN ONLINE JOURNAL OF EDUCATIONAL MANAGEMENT (MOJEM)}

The Results of the interview according to theme as follow:

a) The activities of financial literacy and personal finance.

b) The activities of learning how start up online business legally.

c) The lecture activities of successful entrepreneur to share their experiences to make the youth start to learn entrepreneurship.

d) Visiting the Local Famous Enterprises.

e) Joining adults in the Business Activities such as the youth sell products in supermarket during school holidays.

Participant 1 mentioned that entrepreneurship skills were very important and scored 6.

"Entrepreneurship is very important. It's talking about vibrancy self-sustaining invoice and sustainability. It's about development. Entrepreneur is not only about money in my view. You have to be good in knowledge and skills and attributes. (P1; 1-4)".

He continued to share that the youth needed to learn some entrepreneurship knowledge and skills.

"Of course, strongly agree with that the youth need to learn some entrepreneurship knowledge and skills. Leadership is influencing others. Leadership is how we lead others and how we influence others. We have to say that if we are not entrepreneurs, we don't have the skills and we depend on others. So, we are entrepreneur for ourselves. (P1; 5-9)".

Participant 2 also shared her views on entrepreneurship skills.

"Yes, I do actually believe that the entrepreneurship skills are important for the youth. The world really needs more innovation and more entrepreneurs, and the skills of entrepreneurship are also good life skills.... (P2; 10-13)".

Participant 3 also gave his comments on entrepreneurship skills.

"When one learns entrepreneurship, he or she by themselves can do something without any dependence or depend on others.... (P3; 14-15)".

Participant 4 gave his views on entrepreneurship skills. He said that the youth needed to learn some entrepreneurship knowledge and skills.

"I think entrepreneurship skills are necessary. These are helpful to promote the youth leadership skills. The ability of entrepreneurship needs the spirit of strong persistence, overcoming difficulties, and struggling for achieving goals. Without this spirit entrepreneurship will not be successful. Secondly, the entrepreneurs have many characteristics which are similar to leadership skills. (P4; 16-20)".

He said entrepreneurship skills were very important and scored 6 . He also gave his scores to these specific activities.

"The activities of learning on how start up online business legally is important and scored 6. Visiting the Local Famous Enterprises is moderately important and scored 5. Joining adults in the Business Activities such as the youth sell products in supermarket when they are in school holiday are slight important and scored 3 (P4;25-28)".

Participant 5 also gave his opinions on entrepreneurship skills for the youth: "I think these are extremely important with the scores of 7 because they are prospective....(P5; 34-35)".

Moreover, Participant 7 also gave her understanding on the question of the youth needed learn some entrepreneurship knowledge and skills. 


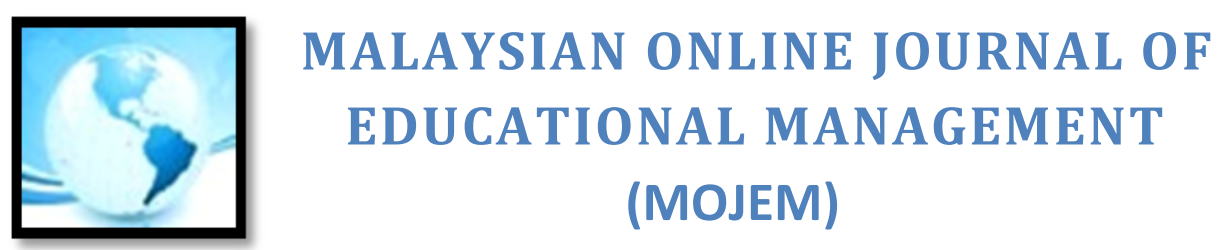

"Yes, in these days, they also need to have knowledge of entrepreneurship. But entrepreneurship skills do help to be a good leader. Because the entrepreneurship skills also need power of wisdom. (P7; 43-45)".

Based on the results of mapping and Interview, the four activities have been classified for the entrepreneurship skills:

a) The activities of learning financial literacy and personal finance

b) The activities of learning on how start up online business legally for the youth

c) The lecture activities of successful entrepreneur to sharing their experiences to make the youth start to learn entrepreneur

d) The activities of visiting the Local Famous Enterprises

Moreover, the questionnaire for Fuzzy Delphi Method (FDM) survey was constructed and the analysis presented into 2 parts: 1). Triangular Fuzzy Numbers; 2) Defuzzification Value. The main element of Entrepreneurship Skills contains four activities. There are listing as following:

a) The activities of learning financial literacy and personal finance;

b) The activities of learning on how start up online business legally for the youth;

c) The lecture activities of successful entrepreneur to sharing their experiences to make the youth start to learn entrepreneurship; and

d) The activities of visiting the Local Famous Enterprises.

After obtaining the consensus of the group, the results were shown as the following:

Table 5

Main Element of Entrepreneurship Skills for FDM

\begin{tabular}{|c|c|c|c|c|c|c|c|c|c|}
\hline \multirow[t]{2}{*}{ No } & \multirow[t]{2}{*}{ Element } & \multicolumn{2}{|c|}{$\begin{array}{c}\text { Triangular Fuzzy } \\
\text { Numbers }\end{array}$} & \multicolumn{4}{|c|}{ Defuzzification Value } & \multirow[t]{2}{*}{ Ranking } & \multirow[t]{2}{*}{$\begin{array}{l}\text { Experts } \\
\text { Decision }\end{array}$} \\
\hline & & 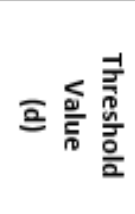 & 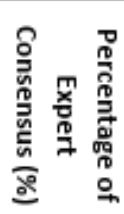 & $\mathbf{m}_{1}$ & $\mathbf{m}_{2}$ & $\mathbf{m}_{3}$ & 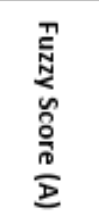 & & \\
\hline 1 & $\begin{array}{l}\text { The activities of } \\
\text { learning financial } \\
\text { literacy and } \\
\text { personal finance. }\end{array}$ & 0.237 & $* 72.0$ & 0.506 & 0.678 & 0.833 & 0.672 & 3 & Accept \\
\hline 2 & $\begin{array}{l}\text { The activities of } \\
\text { learning on how } \\
\text { start up online } \\
\text { business legally for } \\
\text { the youth. }\end{array}$ & *0.443 & *39.0 & 0.378 & 0.533 & 0.683 & 0.531 & - & Reject \\
\hline 3 & $\begin{array}{l}\text { The lecture activities } \\
\text { of successful } \\
\text { entrepreneur to } \\
\text { share their } \\
\text { experiences to make } \\
\text { the youth start to } \\
\text { learn } \\
\text { entrepreneurship. }\end{array}$ & 0.195 & 89.0 & 0.500 & 0.694 & 0.861 & 0.685 & 2 & Accept \\
\hline 4 & $\begin{array}{l}\text { The activities of } \\
\text { visiting the Local } \\
\text { Famous Enterprises. }\end{array}$ & 0.170 & 76.0 & 0.556 & 0.750 & 0.906 & 0.737 & 1 & Accept \\
\hline
\end{tabular}




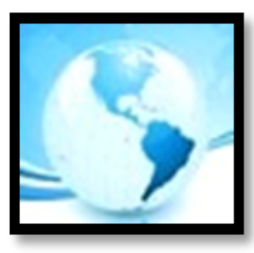

Table 5 indicates that that the mean average for the element of Entrepreneurship Skills. The sub-activity 4 is the activities of visiting the Local Famous Enterprises and the Threshold Value $(d)=0.170$, Percentage of Expert Consensus is 76.0. The average numbers for sub-activity 4 after summing up each row are $0.556(\mathrm{~m} 1), 0.750(\mathrm{~m} 2)$, and $0.906(\mathrm{~m} 3)$, and Fuzzy Score $(A)=0.737$. Based on the conditions of FUZZY DELPHI METHOD (FDM), $d=0.170$ which is less than 0.20, and Percentage of Expert Consensus is 76.0 that is more than 75.0, and Fuzzy Score $(A)=$ 0.737 which is the highest one, so the main element of the activities of visiting the Local Famous Enterprises is accepted and ranked 1.

The sub-activity 2 is the activities of learning on how start up online business legally for the youth and the Threshold Value (d) $=0.443$, Percentage of Expert Consensus is 39.0. The average numbers for sub-activity 2 after summing up each row are $0.378(\mathrm{~m} 1), 0.533(\mathrm{~m} 2)$, and $0.683(\mathrm{~m} 3)$, and Fuzzy Score $(A)=0.531$. Based on the conditions of FUZZY DELPHI METHOD (FDM), $d=0.443$ which is more than 0.20 , and Percentage of Expert Consensus is 39.0 that is less than 75.0 , and Fuzzy Score $(A)=0.531$, so the main element is rejected.

Table 6

Main Element: Entrepreneurship Skills

\begin{tabular}{|c|c|c|c|c|}
\hline \multirow[t]{2}{*}{ Expert } & \multicolumn{4}{|c|}{ Elements } \\
\hline & 1 & 2 & 3 & 4 \\
\hline 1 & 0.428 & 0.640 & 0.274 & 0.196 \\
\hline 2 & 0.252 & 0.337 & 0.039 & 0.356 \\
\hline 3 & 0.300 & 0.519 & 0.039 & 0.196 \\
\hline 4 & 0.070 & 0.058 & 0.278 & 0.356 \\
\hline 5 & 0.428 & 0.640 & 0.407 & 0.333 \\
\hline 6 & 0.070 & 0.282 & 0.039 & 0.060 \\
\hline 7 & 0.070 & 0.282 & 0.039 & 0.060 \\
\hline 8 & 0.070 & 0.519 & 0.039 & 0.060 \\
\hline 9 & 0.070 & 0.282 & 0.278 & 0.060 \\
\hline 10 & 0.252 & 0.058 & 0.278 & 0.356 \\
\hline 11 & 0.070 & 0.337 & 0.039 & 0.060 \\
\hline 12 & 0.252 & 0.618 & 0.274 & 0.196 \\
\hline 13 & 0.428 & 0.337 & 0.583 & 0.196 \\
\hline 14 & 0.252 & 0.618 & 0.274 & 0.196 \\
\hline 15 & 0.070 & 0.282 & 0.039 & 0.060 \\
\hline 16 & 0.070 & 0.820 & 0.039 & 0.060 \\
\hline 17 & 0.070 & 0.519 & 0.274 & 0.196 \\
\hline 18 & 1.040 & 0.820 & 0.278 & 0.060 \\
\hline Threshold value of each item & 0.237 & $* 0.443$ & 0.195 & 0.170 \\
\hline No. of threshold value of item $\leq 0.2$ & 13 & 7 & 16 & 14 \\
\hline $\begin{array}{l}\text { Percentage of threshold value of item } \leq \\
0.2\end{array}$ & $* 72.0 \%$ & $* 39.0 \%$ & $89.0 \%$ & $78.0 \%$ \\
\hline
\end{tabular}

*Reject 


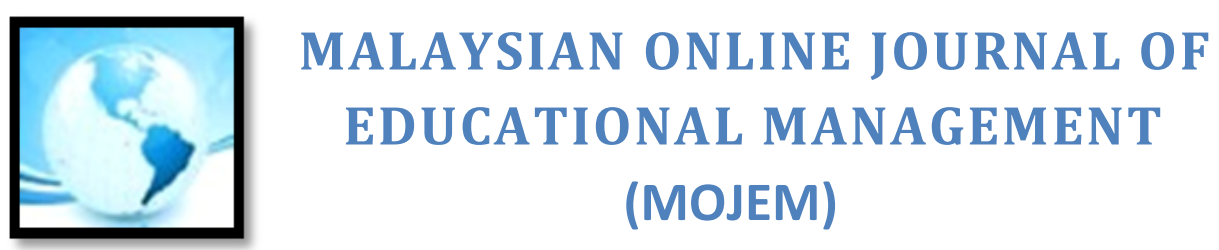

Table 6 indicates that 18 experts' views on the main element of Entrepreneurship Skills. For the activity 1, the highest Threshold value (d) $=1.040$ by Expert 18, and the lowest Threshold value (d) $=0.070$. And based on Percentage of threshold value of item $\leq 0.2,72.0 \%$ of experts rejected. For the activity 2 , the highest Threshold value $(d)=0.820$ by the Expert 16 and 18 . The lowest Threshold value $(d)=0.058$. And based on Percentage of threshold value of item $\leq 0.2,39.0 \%$ of experts rejected. For the activity 3 , the highest Threshold value $(d)=0.583$ by the Expert 13, and the lowest Threshold value $(d)=0$. 039.And based on Percentage of threshold value of item $\leq$ $0.2,89.0 \%$ of experts accepted. For the activity 4 , the highest Threshold value (d) $=0.356$ by Expert 2,4 and 10 , and the lowest Threshold value $(d)=0.060$. And based on Percentage of threshold value of item $\leq 0.2,78.0 \%$ of experts accepted.

\section{DISCUSSION AND IMPLICATION}

In this study, according to the survey questionnaire, the findings have revealed the level of youth entrepreneurship skills based on the students' perception, and the experts' consensus on the activities of youth entrepreneurship skills of the community-based leadership training curriculum content model for the urban youth in China by Fuzzy Delphi Method.

To test the students' youth entrepreneurship skills, the survey questionnaire was applied. The findings revealed that most of items showed medium level of competency. Among these 14 items, 8 items showed medium level of competency and others revealed high level of competency. The highest one of high level of competency was the ability to realise that creativity was important in entrepreneurs $(M=3.87, S D=1.110)$. The findings showed that the young students have the good entrepreneur skills but still need to improve.

Based on the results of Fuzzy Delphi Method in this study, the element of Entrepreneurship Skills, the four activities are measured in the community- based leadership training content model for the urban youth in China and three activities are accepted. Ranking is the important in the Fuzzy Delphi Method. Ranking 1 is the activities of visiting the Local Famous Enterprises. However, the activities of learning on how start up online business legally for the youth is rejected.

According to the findings, the experts have a high acceptance to the entrepreneurship skills and the related activities. The activities of visiting the Local Famous Enterprises is the highest acceptance among these activities reveal that the interesting significant practical way is the effective for training the entrepreneurship skills for the youth. The lecture activities of successful entrepreneur to sharing their experiences to make the youth start to learn entrepreneur reveal that learning the good examples is very useful for the youth to train their entrepreneurship skills. The consensus of the activities of learning financial literacy and personal finance show that teaching entrepreneur theories should be integrated the practical individual experiences. Based on the study of Entrepreneurship Education, the tools of Entrepreneurship Education should be suitable for the teachers to apply easily, which can used as the quality assurance instruments; the emphasises of Entrepreneurship Education are learning -by-doing, practical, and making the connection between the work and the learners, and provide the learners the business communities or occasions; the way of training entrepreneurship should be used the blended learning (combining face-to-face and online learning) which can motive the students and create the real-life situations for the students to practice; the space should be offered for the teachers and trainers to use new tools and programmes, share their experience and learn from their peers from across Europe is highly recommended (Johansen, 2018). The activities accepted by the experts in this study meet the requirements and also are suitable for the recent situation of the urban youth in China. More significant and practical activities for the training of entrepreneurship skills still need to be designed and developed for future studies.

The results of this study are consistent with the Tyler's Model (1949) for curriculum theory in the stages of stating the objectives; selecting the learning experiences; organising the learning experiences which referring to Tyler's basic principles: defining the purpose of the curriculum; defining the education experiences related to the 


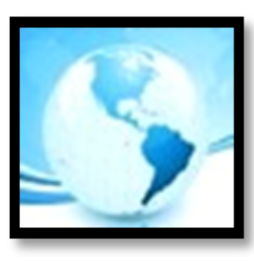

\section{MALAYSIAN ONLINE JOURNAL OF EDUCATIONAL MANAGEMENT (MOJEM)}

purposes; defining the organisation of these experiences; and defining the elevation of the purposes (O'Neill, 2010). Based on Tyler's conceptual framework, the educational objectives are derived from three sources: studies on society, studies by the learners, and subject-matter specialists. Hence, the youth entrepreneurship skills components/ needs of the questionnaire are planed suitably for the reality of the young students and the content of this questionnaire is designed from the previous studies on subject matters and society. This result of this study is also consistent with Institute of International Education (IIE) approach to Managing Youth Leadership Programs (2014), the entrepreneurship skills for the youth is very important and the activities of field visits business simulations, and the basic entrepreneurship skills knowledge are accepted by the young students.

In this study, the important contribution from the results is that entrepreneurship skills need to be designed and train in the Community- Based Leadership Training Curriculum Content Model for the Urban Youth in China. This is also a large gap in the youth leadership training curriculum. Therefore, future studies should add the special context of youth entrepreneurship to serve as systematic support which can be conducted to meet the youths' entrepreneurship needs. The particular activities for training youth entrepreneurship are designed and implemented in a formal classroom and also outdoor visit activities. It requires the course teachers or trainers to prepare and contribute their knowledge to make the appropriate lesson plans for practicing. At last, this model serves as an example for the future researchers to design and develop the community- based leadership training curriculum for the urban youth in China with international perspectives, given the current globalisation trend.

Moreover, this study serves as an example on how Fuzzy Delphi Method is used to evaluate the entrepreneurship skills in educational model. For evaluating the education product model, the existing methodologies include focal group interview, survey questionnaires for teachers and students. In addition, other methodologies have also been used widely, such as Stufebeam's CIPP elevation model (1983) which contains the four elements: C- Context, IInput, P- Process and P- Product which has been used for the evaluation of context and development process in education (Aziz, Mahmood, \& Rehman, 2018). Stake Countenance Model (Stake, 1967; Wood, 2001) focuses on evaluating education product. In this study, Fuzzy Delphi Method is significant for collecting the experts' opinions as the way of making decisions on the complicated problem. As the method for evaluating the outcomes of the study, the implication of Fuzzy Delphi Method serves as an example for the future researchers to design and develop as guided. In fact, for the research which need selecting international views or perceptive by experts, the Fuzzy Delphi method is very effective and this study also give the trend.

\section{CONCLUSION}

The youths in urban cities need improvement in youth leadership knowledge, skills and techniques for their own and community development. They need to be on par with the rapid economic and social development. In addition, although many youth leadership training curricula or programs have already been implemented, the Community-Based Leadership Training Curriculum for the Urban Youth which engaged the perspectives and experiences of western countries and the local context of China urban cities still need to be improved. The focus should also be focused especially on the entrepreneurship skills for the youth which have become more important in recent years. This study was able to explore the entrepreneurship skills level for the urban youth in China and obtain consensus from panel of experts on the activities of entrepreneurship skills that suitable to the Youth Community Based Leadership Training. Based on the results of questionnaire survey by 526 students and Fuzzy Delphi Method applied by panel of 18 experts, the entrepreneurship skills of the urban youth in China is at the good level but still need to be improved. Meanwhile, the three important activities of youth entrepreneurship have the significance for the leadership training: visiting the local famous enterprises; the lecture activities of successful entrepreneur to share their experiences to make the youth start to learn entrepreneurship; and the activities of financial literacy and personal finance.

This study has the contribution for both youth entrepreneurship skills of leadership training and the implementation of Fuzzy Delphi Method to get the experts' decision in leadership training, partially, for the 


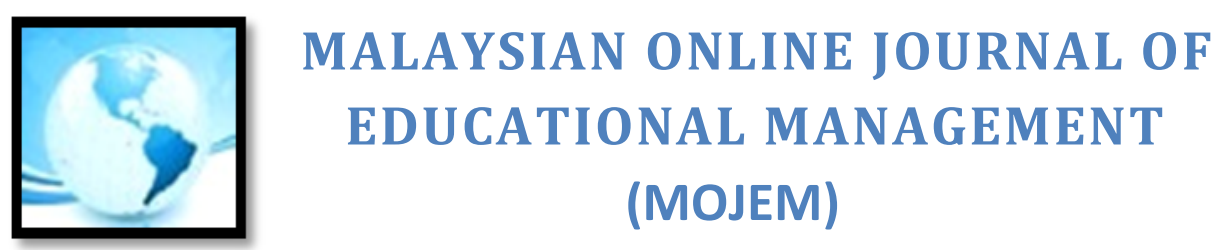

evaluation of the product model. In short, the youth entrepreneurship skills for the youth leadership training can enhance the youth improvement for the urban youth in China and the specific activities of training youth entrepreneurship skills need to design and develop in future studies. By training the youths' entrepreneurship skills, it can effectively help with the demand of the trainers, the schools and the educational organisations with the development of fund of knowledge and rich practical experience sequentially.

\section{REFERENCES}

Abidin, F. Z., \& Bakar, H. (2005). Entrepreneurship Education: The case of Universiti Utara Malaysia. Sintok, Malaysia: UUM Press.

Alexander, R. (2006). Towards dialogic teaching: Rethinking classroom talk. York, UK: Dialogos

Alvarez, S. A., \& Barney, J. B. (2007). Discovery and creation: Alternative theories of entrepreneurial action. Strategic Entrepreneurship Journal, 1(1-2), 11-26.

Aziz, S., Mahmood, M., \& Rehman, Z. (2018). Implementation of CIPP model for quality evaluation at school. Journal of Education and Educational Development, 5(1), 189-206.

The America's Promise Alliance. (2006). Every child, every promise: turning failure into action report. Retrieved from

https://www.google.com/url?sa=t\&source=web\&rct=j\&url=http://www.amchp.org/programsandtopics/Ad olescentHealth/resources/Documents/America\%2527s-Promise-

presentation.pdf\&ved=2ahUKEwjJI7K71fviAhUGro8KHXx9DxUQFjADegQIBBAB\&usg=AOvVaw1gbpe9w0bQ5 TOocv8fUZUd\&cshid=1561157918020

Brady, B., Dolan, P., Kearns, N., Kennan, D., McGrath, B., Shaw, A., \& Brennan, M. (2012, November). Understanding Youth Civic Engagement: Debates, Discourse and Lessons from Practices. Report prepared for Social Entrepreneurs Ireland (SEI) by the UNESCO Child and Family Research Centre, NUI Galway.

Christmann, A., \& Van Aelst, S. (2006). Robust estimation of Cronbach's Alpha. Journal of Multivariate Analysis, 97(7), $1660-1674$.

Deng, X. (2015). China youth population and development statistics report in 2014. Social Investigations, 34(177), 7-11.

Doherty, S. (2003). A model for community-based youth leadership development. Effective Communities Project. Retrieved May, 4, 2007 from https://effectivecommunities.com/wpcontent/uploads/2017/09/ECP_YouthLeadership.pdf

Education into Employment. (2012). Youth entrepreneurship training program. Pilot Phase, March to July 2012 Activity Report. pp.1-31. Retrieved from https://318c4w1xeg053utxpp3we7qcwpengine.netdnassl.com/wpcontent/uploads/2012/08/ActivityReport_-Entreprenesurhip-Training-Program_-Pilot-Phase.pdf

Finstad, K. (2010). Response interpolation and scale sensitivity: Evidence against 5-point scales. Journal of Usability Studies, 5(3), 104-110.

Gordon, S., \& Taft, J. K. (2010). Rethinking youth political socialization: Teenage activists talk back. Youth \& Society, 43(4), 1499-1527. 


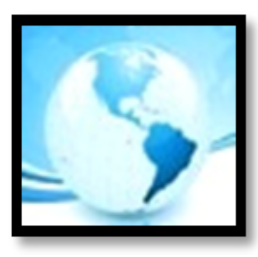

\section{MALAYSIAN ONLINE JOURNAL OF EDUCATIONAL MANAGEMENT (MOJEM)}

Hayton, J. (2015). Leadership and management skills in SMEs: Measuring associations with management practices and performance. Retrieved from https://www.gov.uk/government/uploads/system/uploads/attachment_data/file/4076 24/BIS-1595_Leadership_and_Management_Skills_in_SMEs.pdf

Hesselbein, F., \& Goldsmith, M. (2006). The leader of the future 2: Visions, strategies, and practices for the new era. USA: Leader to Leader Institute.

Hunter, M. (2012). On some misconceptions about entrepreneurship. Economics, Management, and Financial Markets, 7(2), 55-104.

Johansen, V. (2018). Innovation Cluster for Entrepreneurship Education Research Project on the impact entrepreneurship education. Retrieved from https://www.researchgate.net/publication/327623618_Innovation_Cluster_for_Entrepreneurship_Educatio n/download

Kahn, L., Hewes, S., \& Ali, R. (2009). Taking the lead: Youth leadership in theory and practice. The Young Foundation. Retrieved from https://youngfoundation.org/wp-content/uploads/2012/10/Taking-the-Lead-October-2009.pdf

Karagianni, D., \& Montgomery, A. J. (2016). Developing leadership skills among adolescents and young adults: A review of leadership programmes. International Journal of Adolescence and Youth, 23(1), 86-98.

Kress, C. (2004). The essential elements of 4-H Youth Development: Distillation to four elements. Washington, DC: CSREES/USDA.

Lerner, R. M. (2004). Liberty: Thriving and civic engagement among America's youth. Thousand Oaks, CA: Sage.

Li, J., \& Lang, W. (2012). Significance and strategy of leadership training for middle school students. Teaching Research, 35(4), 111-113.

Lin, S. (2016). Research report on the promoting of leadership development of high school students by the course: Leadership development of middle school students. Mental Health Education for Middle School Students, 2(1), 8-12.

Lunenburg, F. C. (2011). Theorizing about curriculum: Conceptions and definitions. International Journal of Scholarly Academic Intellectual Diversity, 13(1), 1-6.

MTD Training. (2010). Effective Communication Skills. Retrieved from http://promeng.eu/downloads/trainingmaterials/ebooks/softskills/effectivecommunication-skills.pdf

O'Neill, G. (2010). Program Design: Overview of curriculum models. pp.1-12. Retrieved from https://www.ucd.ie/t4cms/UCDTLP00631.pdf

Pan, J. P., Wang, F., Zhang, H., Zhang, S. J., Yang, Z. N., Wang, W. Q., . . . Niu, Q. (2012). The status of child neglect for children aged 3-17 in China. Chinese Journal of Preventive Medicine, 46(1), 28-32.

Search Institute. (1997). 40 Developmental Assets. CBO Fact Sheet. Retrieved from https://www.searchinstitute.org/wp-content/uploads/2018/02/2007-Roehlkepartain-Assets-SL-NSLC.pdf 


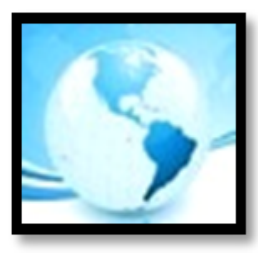

\section{MALAYSIAN ONLINE JOURNAL OF EDUCATIONAL MANAGEMENT (MOJEM)}

Stake, R. (1967). The countenance of educational evaluation. Teachers College Record, 68(7), 523-540.

Tavakol, M., \& Dennick, R. (2011). Making sense of Cronbach's Alpha. International Journal of Medical Education, 2(2), 53-55.

The ASPIRA Youth Leadership. (2012). Development curriculum: Facilitator's guide. Retrieved from https://aspira.org/sites/default/files/ Facilitator\%27s\%20Guide 202012-V3.pdf

Tyler, R. W. (1949). Basic principles of curriculum and instruction. Chicago, IL: University of Chicago Press.

United Nation. (2015). Population Facts: Youth population trends and sustainable development. Retrieved from http://www.un.org/esa/socdev/documents/youth/fact-sheets/YouthPOP.pdf

Vassiliou, A. (2013). Focus on: Young people and entrepreneurship: European good practice projects. Retrieved From https://www.salto-youth.net/downloads/4-17-2610/Focus OnYouthEmployment.pdf

Wood, B. B. (2001). Stake's countenance model: Evaluating an environmental education professional development course. The Journal of Environmental Education, 32(2), 18-27.

World Population Prospects. (2017). World population prospects: Key findings \& advance tables. New York, NY: United Nations.

Youth Entrepreneurship Training. (2013). Program Second Phase. Retrieved from http://survivorsfund.org.uk/wp-content/uploads/2013/09/YETP2.pdf

Youth and Leadership Training. (2014). WAY Report. Retrieved from https://www.way.org.my/files/youth_issues/Youth_and_Leadership_training.pdf

Youth Development of Executive of King County. (2013). Youth skills and beliefs survey. Retrieved from http://cypq.org/sites/cypq.org/files/2013\%20YDEKC\%20Youth\%20Skills\%20and\%20Beliefs\%20Survey\%20 PAPER\%20FINAL.pdf 